Mid-American Review of Sociology

These faults need not be fatal as the majority of the text is readable and sound. It is accompanied by a better-than-average teacher's guide which contains chapter outlines, suggested films and additional readings as well as test questions. The fact that this text is available in a paperbound edition is an additional plus.

Kansas State University

Vickie Weeks

\section{Review Essay: Education and the Radical Critique}

"This is the fate of our times, to live in a society characterised by mechanised petrification."

\section{Max Weber}

"(I)t is men who change circumstances and it is essential to educate the educator himself."

\section{Karl Marx}

This essay will be primarily concerned with a critical analysis of recent writings pertaining to schooling in America. Included in the analysis will be the work of Samuel Bowles, Martin Carnoy, Herbert Gintis, Michael Katz, and Joel Spring. Although these scholars of American education will provide the theoretical framework for the essay, they do not necessarily concur on all issues. As we will later demonstrate, all of the works differ in many instances, especially their policy recommendations. If there is a common thread woven throughout all of these works, it is the intellectual debt they owe Karl Marx. All of them rely heavily on Marxian materialism in their analyses, but few utilize the Marxian dialectic to its fullest. The task of the essay will be an explication of the theories and subsequent policy recommendations of the works under scrutiny followed by a critical evaluation of the theory and its proposed praxis (or lack thereof).

In the studies which form the substance of this essay, schools are seen as socializing institutions serving as instrumentalities for those in social, economic, and political control. Those in power use education to reproduce the social structure in which they are powerful. For example, Carnoy states his major thesis:

We argue that the way society organizes formal schooling is a function of the economic and social hierarchy and cannot be separated from it. We contend that the schools function to reinforce the social relations in production, and that no school 
reform can be separated from the effect it will have on the hierarchical relations in the society (Carnoy, p. 343).

Spring echoes these sentiments in slightly different language.

The school is and has been an instrument of social, economic, and political control. It is an institution which consciously plans to turn people into something. Within this framework the school must be viewed as an instrument of power. It creates an institutional relationship which gives power to a social group to consciously shape the personality and goals of an entire generation. Those in control could be all adults, businessmen, teachers, professional bureaucrats, or politicians. Since 1900, the power of schooling has tended to be in the hands of businessmen, political leaders, and professional educators who have been instrumental in the development of the modern corporate state (Spring, p. 149).

Katz views the schools in much the same light:

For the schools are fortresses in function as well as form, protected outposts of the city's educational establishment and the prosperous citizens who sustain it. In their own way, they are imperial institutions designed to civilize the natives; they exist to do something to poor children, especially, now, children who are black or brown. Their main purpose is to make these children orderly, industrious, law-abiding, and respectful of authority (Katz, p. XViii).

In their ambitious study, Bowles and Gintis postulate that the educational system mirrors or reflects the economic system and therefore transmits those values most supportive of advanced monopoly capitalism. They view the schooling process as performing two primary functions: 1) it reproduces social relations which replicate the hierarchical division of labor within the economic system; and 2) it reinforces socio-economic inequality (Bowles and Gintis, p. 11-14). It is not an exclusively modern idea to suggest that the manner in which a society goes about meeting its economic needs (and in the process establishes definite social relations) influences in a dramatic way the manner in which that society goes about the educational process. Approximately one hundred and thirty years ago, Marx and Engels, writing in the German Ideology, articulated this concept:

The ideas of the ruling class are in every epoch ruling ideas: i.e., the class which is the ruling material force of society, is at the same time its ruling intellectual force. The class which has the means of material production at its disposal, has control at the same time over the means of mental production, so that thereby, generally speaking, the ideas of those who lack the means of mental production are subject to it (Marx and Engels, p. 136).

A major premise advanced by these scholars is that the process of schooling is primarily concerned with inculcating each pupil with the dominant cultural biases of a particular society. These cultural biases are, consequently, reflective of the interests of the dominant socio-economic class. This function is irreverently depicted by Ronald Laing, the well-known British psychiatrist, as "tricking children out of their minds".

We begin with the children. It is imperative to catch them in time. Without the most thorough and rapid brainwashing their dirty minds would see through our dirty tricks. Children are not yet fools, but we shall turn them into imbeciles like ourselves, with high I.Q.'s if possible... By the time the new human being is fifteen or so, we are left with a being like ourselves, a half-crazed creature more or less adjusted to a mad world. This is normality in our present age (Laing, p. 58).

These studies also indicate that, as well as being transmitted through the explicit school curriculum, cultural biases may be effectively taught through the day-to-day functioning of the school itself (the insidious curriculum). It is this latter process which receives most of the attention of these studies. It is their view that through its organizational structure, the American school places a premium on behavioral characteristics such as punctuality, subordination, and compartmentalization. In essence, 
through its organizational structure, the American school cultivates and rewards specific kinds of behavior which are demanded by the hierarchical division of labor within the economic system. Katz offers this relevant insight concerning the purpose of schooling.

The purpose has been, basically, the inculcation of attitudes that reflect dominant social and industrial values; the structure has been bureaucracy. The result has been school systems that treat children as units to be processed into particular shapes and dropped into slots roughly congruent with the status of their parents (Katz, p. XViii).

Bowles and Gintis reiterate the fact that the educational system is the hand-maiden of the economic system. It produces young people who possess the needed primary skills, as well as the important attitudinal conditioning, which is deemed ever-so important in the contemporary work setting.

The educational system, basically, neither adds to nor subtracts from the degree of inequality and repression originating in the economic sphere. Rather, it reproduces and legitimates a preexisting pattern in the process of training and stratifying the work force. How does this occur? The heart of the process is to be found not in the content of the educational encounter-or the process of information transfer-but in the form: the social relations of the educational encounter. These correspond closely to the social relations of dominance, subordination, and motivation in the economic sphere. Through the educational encounter, individuals are induced to accept the degree of powerlessness with which they will be faced as mature workers (Bowles and Gintis, p. 265).

Spring views this process as the primary initiation rite in the preparation of young adults as they pass into the alienated roles of mature adult workers.
The triumph of the school in the twentieth century has resulted in the expansion of this concept of alienation. Technology and state capitalism still make work meaningless to the individual and create a condition of alienation from the product of labor. The school increases this alienation by making alien the very ability of the individual to act or create. In school the ability to act is no longer an individual matter but is turned over to experts who grade, rank, and prescribe. Activity, itself, no longer belongs to the individual but to the institution and its experts. In the nineteenth century man lost the product of his labor; in the twentieth century man lost his will (Spring, p. 154).

Education has traditionally been viewed as a vehicle of upward social mobility. The literature is replete with numerous passages depicting schooling as the key to the American Dream. Carnoy challenges this assumption and offers us his version of the school as a legitimatizing agency:

In this study we have stressed that schools help maintain a hierarchical structure, and help ensure that the same class of people end up at the top of the hierarchy in each generation, and the same class at the bottom. We contend that schools are able to legitimize grossly unequal access to goods and services in a capitalist society by colonizing children and their families to believe in the brand of "meritocracy" implemented by the schools. .. (Carnoy, p. 364).

Throughout his book, Carnoy argues that schools in capitalist societies promote the acceptance of inequitable roles in the economy and society as a just and correct way of organizing human relations (Carnoy, pp. 13-20). Katz, too, questions the conventional wisdom of educational achievement as a means of upward mobility:

Despite the existence of free, universal, and compulsory schooling, most poor children become poor adults. Schools are not great democratic engines for identifying talent and matching it with 
opportunity. The children of the affluent by and large take the best marks and the best jobs (Katz, p. XViii).

In their analysis, Bowles and Gintis also question the assumption that higher incomes result from more education. They posit a counter hypothesis-the amount of income and the amount of education are both mainly determined by the initial socio-economic position of the individual (Bowles and Gintis, p. 30). A person selected at random in the top ten percent of the income distribution is likely to receive five more years 'of education-college plus a year-than one coming from the bottom ten percent of the income heap (Bowles and Gintis, p. 30). Even among high school graduates, children of families with incomes over $\$ 15,000$ per annum were six times as likely to enter college as children of families with poverty incomes. Even more alarming, among individuals with the same IQ, persons coming from the top of the income ladder are likely to receive over four more years of schooling than those at the bottom of the ladder (Bowles and Gintis, pp. 31-32).

Accordingly, these studies assert the undeniable fact that human capital is not amassed willy-nilly, or in direct proportion to "intelligence," but primarily as the direct result of one's initial socio-economic position. The affluent get more education because they are affluent and, if education is the key to subsequent income, they thereby perpetuate and enhance their economic advantage. Therefore the public school system cannot function as an instrument for redressing inequality. Its primary task is to identify and certify losers, rather than to redeem them.

\section{Summary of Policy Recommendations}

If, as these studies conclude, our schools are repressive and not conducive to fostering the kinds of values that a reasonable society requires, what steps are necessary to change them? All of the above-cited authors conclude their analyses with recommendations which are designed to assist others in their efforts to act upon their social and material world.
Katz suggests four areas of reform:

1) Abolish compulsory schooling and provide alternative ways for young people to live and grow.

2) Decentralize and shift power away from administrators to local communities, teachers, and schools.

3) Require schools to concentrate on strictly educational tasks and exclude conscious attempts to formulate social attitudes.

4) Carry on the business of learning simply, directly, and informally in small groups-meeting wherever space is available rather than in large, complex institutions (Katz, pp. 140-145).

Carnoy's recommendations revolve around the issue of raising consciousness. For him, change in the educational structure is a prerequisite to change in the economic and political arena. "... for any transformation requires changing people's understanding of the social contract and the meaning of the work, responsibility, and political participation" (Carnoy, p. 366). Alternative schools then become Carnoy's answer. By alternative or "free" schools, he means those which allow people to "love and collaborate in work to 'enhance their ability to tend and care and wait upon the other' " (Carnoy, p. 367). He cautions:

(I)f these schools are to be a true alternative, they must face the issue of who runs the society and why. Teachers and students must also face their own reality in the school, and the function of that institution in perpetuating inequities (Carnoy, p. 369).

Spring, unlike his colleagues, does not see schooling as something to reform, but rather as something to eradicate. Very much in the tradition of Ivan Illich, he warns of the ominous consequences of employing the school as a vehicle for socialization.

The solution is not to change the goals and direction of socialization and social control. This is impossible. As long as the public schools take responsibility for the socialization of the child, social adaptation to the institution becomes inevitable. The 
Mid-American Review of Sociology

standards of freedom and individual life styles are determined by the organizational requirements of the institutions. Any talk about changing the goals of socialization without considering these factors is meaningless. The only possible solution is ending the power of the school (Spring, pp. 171-172).

In their recommendations, Bowles and Gintis suggest nothing less than a socialist revolution. They find the track records of such reform movements as the Progressives and the more recent "free school proponents" extrememly wanting. They propose significant and far-reaching economic reforms which will generally be brought about by alienated and dissatisfied workers. They reiterate the Marxian speculation "that the continued expansion of the forces of production under capitalism might necessitate the development of a labor force whose skills and outlook would bring it into conflict with the social relations of production" (Bowles and Gintis, p. 206). In their view, it is this apparent contradiction of monopoly capitalism which will generate the appropriate consciousness to enable workers to bring about a new order.

Turning to the new order, Bowles and Gintis comment on their strategy:

An educational system can be egalitarian and liberating only when it prepares youth for fully democratic participation in social life and a equal claim to the fruits of economic activity.... Thus we believe that the key to reform is the democratization of economic relationships: social ownership, democratic and participatory control -of the production process by workers, equal sharing of socially necessary labor by all, and progressive equalization of incomes and destruction of hierarchical economic relationships. This is, of course, socialism, conceived of as an extension of democracy from the narrowly political to the economic realm (Bowles and Gintis, p. 14)

The core of their American Socialism would consist in the development of an alternative to the wage-labor system.
Review Essay: Education and the Radical Critique

\section{Critical Evaluation of Findings and Policy Suggestions}

As was suggested in the early part of this essay, all of the studies under consideration utilize, in varying degrees, a form of Marxian materialism to explain the schooling process. To use only the materialism of the Marxian method distorts the reality one wishes to describe. According to Marx, one aspect of our existence is composed of our material and social environment. But this aspect alone does not explain objective reality. Social existence includes not only our material environment, but our response to it. For Marx, the human being is an active agent-she/he is influenced by the natural and social environment and through the act of producing her/his means of subsistence influences and alters her/his environment. "History makes man and man makes history." The problem with using historical determinism exclusively to explain past or present reality is that you invariably exclude individual choice and action either by positing that they are wholly conditioned by other factors or by ignoring them altogether.

If we are to formulate policy in such a manner so that human beings are not treated as objects (things), then we must have a complete picture of the schooling dialectic. We must know not only the material and social conditions of schooling, but we must also be informed as to how different individuals act and react in this environment. With the possible exception of Bowles and Gintis, the fallacy of the vulgar materialistic method employed by these studies is most evident in their policy recommendations, i.e., for only by ignoring the assumptions of their theory is it possible for Carnoy, Katz, and Spring to recommend actions that might lead to change.* If economic factors determine power and power determines education why bother with any attempts to change
education?

*Later in the essay we shall see that Bowles and Gintis foresee this contradiction and subsequently look to the economic arena for change to occur. 
Mid-American Review of Sociology

This is the most glaring shortcoming of their policy recommendations. If Katz and Spring are serious about the accuracy of their analysis, how can they suppose that compulsory education could be abolished? After 140 pages of rigorous socio/historical analysis, Katz simplistically suggests that schools should concentrate on "strictly educational tasks to the exclusion of social attitudes." This vague recommendation reflects a naive, if not totally irresponsible, approach to the problem. Equally important, if Carnoy's contention that education mirrors the economic and political hierarchy is correct, how will "raised consciousness" be made possible through the schools? These scholars seem to be implying one of two things-either their analysis is irrelevant to the practical issues of educational change or it is a totally inadequate view of the process of schooling. Consequently, as a theoretical policy-making model, historical materialism as employed by these writers, contains its own seeds of destruction.

Another critical area of concern with these studies is the validity of the correspondence theory. According to their analysis, the socio-economic structure and the schools work hand-in-hand to reproduce young adults fitted to the needs of a capitalistic industrial society. Here, of course, they run the risk of rather simple-minded functionalism whereby everything fits together in its appropriate category.

The educational system has not been that successful, nor has industrial capitalism... . The authors themselves are examples, as are rebels and reformers of recent years who are products of the educational system which was to "reproduce" them (Gamson, p. 24).

In reviewing the work of Bowles and Gintis, Karier comments further concerning the shortcomings of the correspondence theory:

The correspondence theory which they develop and use throughout their study has some distinct weakness, however. While few would
Review Essay: Education and the Radical Critique

care to disagree with the proposition that the schools have generally reflected the larger economic social order, many will disagree with the exact correspondence of the workplace to the educational system. As they draw the relationship between the workplace and schooling tighter and tighter, they tend to fall into the trap of making causal claims from correlational studies. Thus because they show a strong parallel between the values developed in the schools and those needed in the workplace, they go on to assume that changes in production in the workplace caused the values produced in education. This, of course, need not necessarily be the case. At least they have not proven it. Here they lack solid historical evidence as to what was going on in the schools to fully substantiate their case. They further assume that if structure of production preceded parallel changes in schooling then the case is made for a causal claim (Karier, pp. 185-186).

Tangential to the correspondence thesis is the crucial question of what does schooling look like in societies which employ other kinds of economic arrangements. All of these studies argue that the noxious educational systems which they depict are the consequence of capitalistic economies. However, none offer evidence of comparative studies to substantiate their claims. Jencks, although restricting his criticism to Bowles and Gintis, offers a critique which applies to all of the works discussed in this essay.

The authors also ignore obvious objections to their historical and political arguments. Thus, they define capitalism as private ownership of the means of production combined with widespread wage labor. They claim that capitalism, so defined, is the root cause of hierarchical organization in both schools and economic institutions. Yet schools were hierarchical and repressive even at the time of the American Revolution, when wage labor was almost unknown and the great majority of white citizens were self-employed. Schools are also hierarchical and repressive in the Soviet Union and Eastern Europe, where the means of production are owned by the state. If one wants to show that capitalism is at 


\section{Mid-American Review of Sociology}

the heart of America's educational problems, one must show that non-capitalist societies are less prone to such problems. Bowles and Gintis make no effort to do this (Jencks, p. 18).

As was mentioned above, Bowles and Gintis' study is the only one which imploys the Marxian dialectical analysis. We may quarrel with their recommendations or with their inability to articulate a complete picture of schooling, but we cannot fault their dialectical methodology. They see the material world (specifically the workplace) providing the tension (alienation) which eventually will lead to an increased awareness (raised consciousness) of the contradictions of the capitalist system. Through their interaction with the social relations of production, workers act on their world and, in fact, change their world. According to Bowles and Gintis, liberating education will follow the workers' revolution.

This is dialectical analysis to be sure, but it does not address itself to the tensions or contradictions growing out of the schooling process. Bowles and Gintis tell us what is happening in the workplace, but not in the schoolyard. We only see one dimension of schooling-the structural or material setting. We are not informed concerning how humans act and react to this structure which attempts to reproduce them in the likeness of an economic input.

In fact, what these studies tell us, but fail to sufficiently probe, is that there are cracks in this system called capitalist schooling. Carnoy's admittance that even colonial schools unintentionally teach children to question, (pp. 57,58, \& 72) indicates that the colonial relationship does not automatically mean that schooling serves only to reinforce cultural imperialism. These contradictions, these cracks in the system, are crucial issues which are left unexamined. Consequently, it is this important dialectic which requires our most serious attention.

Washington University

Larry Van Sickle
Review Essay: Education and the Radical Critique

\section{REFERENCES}

Bowles, Samuel and Herbert Gintis

1976. Schooling in Capitalist America: Educational Reform and the Contradictions of Economic Life. New York: Basic Books, Inc.

Carnoy, Martin

1974 Education as Cultural Imperialism. New York: David McKay Company, Inc.

Gamson, Zelda

1977 "A Review of Feinburg and Rosemont Jr., Work, Technology, and Education. Contemporary Sociology 6 (January):23-24.

Jencks, Christopher

1976 "A Review of Bowles and Gintis. Schooling in Capitalist America." The New York Times Book Review (February 15):17-18.

Karier, Clarence

1976 "The Odd Couple: Radical Economics in Liberal History." Educational Studies 7 (Summer):185-194

Katz, Michael

1975 Class, Bureaucracy, and Schools: The Illusion of Educational Change in America. New York: Praeger Publishers, Inc.

Laing, Ronald

1967 The Politics of Experience. New York: Ballantine Books, Inc.

Marx, Karl

1972 The German Ideology in Robert Tucker (ed.), The Marx-Engels Reader. New York.

Spring, Joel

1972 Education and the Rise of the Corporate State. Boston: Beacon Press. 